Received:

$15-\mid-2020$

Accepted:

6-IV-2020

Published Online: 27-IV-2020

\section{Management of Recurrence of Ameloblastoma and Odontogenic Keratocyst: A Cross-Sectional Study}

\author{
Manejo de la recurrencia del ameloblastoma y keratoquiste \\ odontogénico: Estudio de corte transversal
}

Onur Yilmaz DDS1; Zeynep Sagnak Yilmaz MD²; Emre Balaban DDS33; Celal Candirli DDS, PhD4

1. Department of Oral and Maxillofacial Surgery, Faculty of Dentistry, Karadeniz Teknik University, Trabzon, Turkey.

2. Department of Pathology, Kanuni Training and Research Hospital, Trabzon, Turkey.

3. Department of Oral and Maxillofacial Surgery, Faculty of Dentistry, Recep Tayyip Erdogan University, Rize, Turkey.

4. Department of Oral and Maxillofacial Surgery, Faculty of Dentistry, Saglık Bilimleri University, Istanbul, Turkey.

Correspondence to: Dr. Onur Yilmaz - onuryilmaz590@hotmail.com

ABSTRACT: Objectives: Odontogenic keratocyst (OKC) and ameloblastoma are slowly growing and locally invasive tumors with high recurrence rate. The aim of this study was to investigate the clinicopathologic features of recurrent ameloblastoma and OKC cases, and evaluate outcomes of our treatments in terms of recurrence. Material and Methods: A total of 23 patients with confirmed recurrent ameloblastoma or OKC and treated in our clinic within eleven years period were reviewed retrospectively. Results: Eleven recurrent OKC cases and twelve recurrent ameloblastoma cases were included. Most recurrences occurred within five years after the initial treatment $(69.6 \%)$. Enucleation had the highest recurrence rate among the first treatments (18/23). All recurrences were located in the mandible, with one exception (22/23). All recurrent OKCs were multilocular. Different histopathologic subtypes of ameloblastoma were seen in our study, follicular ameloblastoma was the most common (8/12). The mean diameter of the lesions was $4.3 \mathrm{~cm}$ (ranging from $2 \mathrm{~cm}$ to $7 \mathrm{~cm}$ ). Statically significant relation was found between location and diameter of lesion and year of recurrence onset $(p=0.004 ; p=0.026)$. We performed radical treatments in these cases (ten patients underwent marginal resections, and thirteen patients underwent segmental resection), and no recurrence was observed during the follow-up period. Conclusion: Previous inadequate surgical procedures were the most important cause of recurrence. Marginal or segmental resection with safety margins is the best method to treat recurrences of $\mathrm{OKC}$ or ameloblastoma cases.

YILMAZ O., SAGNAK Z., BALABAN E., CANDIRLI C., 2020: Management of Recurrence of Ameloblastoma and Odontogenic Keratocyst: A CrossSectional Study.-ODOVTOS-Int. J. Dental Sc., 22-3 (September-December): 174-186. 
KEYWORDS: Odontogenic Tumours; Odontogenic Cysts; Recurrence; Conservative Treatment; Margins of Excision; Resection.

RESUMEN: Objetivo: Los keratoquistes odontogénicos (KQ0) y ameloblastomas son tumores invasivos de lento crecimiento local con una alta tasa de recurrencia. El propósito de este estudio fue investigar las características clínico patológicas de los casos de ameloblastoma y KQO recurrentes y evaluar los resultados de tratamientos en término de recurrencia. Materiales y Métodos: Un total de 23 pacientes con casos confirmados de ameloblastomas o KQO recurrentes tratados en nuestra clínica en un período de once años fueron incluidos. Resultados: Once casos de KQO recurrentes y doce ameloblastomas recurrentes fueron incluidos. La mayoría de las recurrencias ocurrieron en los primeros 5 años posteriores al tratamiento inicial (69.6\%). La enucleación mostró la tasa de recurrencia más alta entre los tratamientos iniciales (18/23). Todas las recurrencias se presentaron en la mandíbula excepto por un caso (22/23). Todos los KQO fueron multiloculares. Distintos subtipos histológicos del ameloblastoma fueron detectados en el estudio y el ameloblastoma folicular fue el más común (8/12). El diámetro promedio de las lesiones fue de $4.3 \mathrm{~cm}$ en un rango de $2 \mathrm{~cm}$ a $7 \mathrm{~cm}$. Una relación estadísticamente significativa se encontró entre la ubicación y el diámetro de la lesión y el tiempo de aparición de la recurrencia $(p=0.004 ; p=0.026)$. Se realizaron tratamientos radicales en los siguientes casos, diez pacientes tuvieron resecciones marginales y trece pacientes resección segmental; no se observaron recurrencias en el período de seguimiento. Conclusión: Procedimientos previos inadecuados fueron la causa más relevante de recurrencia. Resección marginal 0 segmental con márgenes de seguridad son el mejor método para tratar casos de ameloblastoma y $\mathrm{KQO}$ recurrentes.

PALABRAS CLAVE: Tumores odontogénicos; Quistes odontogénicos; Recurrencia; Tratamiento conservador.

\section{INTRODUCTION}

Odontogenic keratocyst (OKC) and ameloblastoma are common pathological lesions of the jaws. These are important entities because of their locally destructive natures, extension potential into adjacent tissues, high recurrence rates, and characteristic histologic appearances. Both are often misdiagnosed and undertreated, which may lead to recurrence (1-4).

Odontogenic keratocyst is a benign, intraosseous neoplasm with aggressive and infiltrative characteristics that originates from the remnants of the dental lamina $(1,2)$. It has a characteristic lining of parakeratinized stratified squamous epithelium. The lesion was first described in 1956 as an odontogenic keratocyst to indicate the keratinization of the epithelial lining $(3,4)$. The recurrence rate after removal of the lesion is very high $(5,6)$. Recurrence rate and morbidity highly associated with treatment modality, and the most appropriate treatment method has been controversial $(4,5)$. Treatment modalities in the literature include decompression, marsupialization, curettage, enucleation, and more 
invasive methods, such as radical enucleation and resection $(1,2,7)$.

Ameloblastomas are benign, locally invasive odontogenic tumors with an epithelial origin comprising $10 \%$ of all jaw tumors (8). Ameloblastoma was first recognized by Cusack in 1827 and was named in 1930 by lvy and Churchill (9). The origin cells of ameloblastoma are thought to be ameloblast. This hypothesis is based on that cells of origin are epithelial and may express the precursor of enamel, amelogenin (8). Although typically benign and slow growing, ameloblastoma causes expansion, eventually resulting in perforation of the cortical bone and infiltration of surrounding soft tissues $(10,11)$. Ameloblastomas have a risk of local recurrence with the magnitude depending on the histological type and surgical treatment method $(9,11)$.

Limited data are available on the clinical and histological features of patients with recurrent OKC or ameloblastoma, and there is still no adequate evidence in the literature to support any treatment modality as the most effective for recurrent cases. The aim of this study was to identify clinical and radiological profile of recurrent ameloblastoma and OKC cases and evaluate the efficacy of our treatments in terms of recurrence.

\section{MATERIALS AND METHODS}

This study was conducted in compliance with the principles of the Declaration of Helsinki, and approval of the ethics committee required for the study was obtained from the Ethics Committee of the Karadeniz Technical University (2019/276). Informed consent was obtained from all individual participants included in the study. To address the research purpose, the investigators designed and implemented a cross-sectional study with patients' records. The study population consisted of patients with recurrent ameloblastoma or OKC, treated at the Department of Oral and Maxillofacial
Surgery of Karadeniz Technical University Faculty of Dentistry (Trabzon, Turkey) between 2007 and 2018. We analyzed records of patients with recurrent ameloblastoma or OKC referred to our clinic during the eleven years period.

Among the available patients' records the inclusion criteria were: (1) confirmation of ameloblastoma or OKC histological diagnosis according to the WHO recommendation, (2) patients who had a history of at least one previous surgery in different centers and recurrences due to insufficient treatment, follow-up or other reasons, (3) minimum documented follow-up period of 3 years. Patients were excluded if they presented any of the following criteria: (1) patients who refused to participate in the study after reading the informed consent form, (2) patients with any systemic disease that would prevent tissue healing, (3) patients with nevoid basal cell carcinoma syndrome (Gorlin-Goltz syndrome), (4) cases with inadequate demographic information and invalid follow-up data.

Our treatment plans depended on the patient's history, radiographic examinations including panoramic X-ray or computed tomography (CT), and histopathological findings of the lesions. We performed radical treatments such as marginal or segmental resection with a safety margin of at least $1 \mathrm{~cm}$ beyond the radiographically visible margins in these patients and evaluated their efficacy for recurrence. The lesion-related soft tissues were excised. Reconstruction of cases was performed in same surgical procedure with anterior iliac bone graft, vascularized fibula graft, TMJ prosthesis or a reconstruction plate alone. All patients were followed clinically and radiographically by periapical and panoramic $X$-ray. If doubt of recurrence existed, a dental scan computer tomography was performed. Periodic follow-up examinations were performed every 6 months for the first 2 years and every 12 months for the following years. 
The collected data includes age, gender, tumor location, the first diameter of the lesions (measured on panoramic radiograph), previous treatments, histological findings, association with impacted teeth, number of recurrences, year of recurrence onset, our treatment modalities and reconstruction methods, and follow-up period. The relations between collected data were investigated. Recurrent ameloblastoma or OKC was defined as a relapse after a minimum disease-free period of 1 year following initial surgery. Statistical analysis was performed using SPSS for Windows 17.0 (SPSS, Inc, Chicago, IL). Descriptive statistics were given as frequency, and mean and standard deviation values. Chi-square tests were used to determine statistically significant differences. Statistical significance was set at $p<0.05$.

\section{RESULTS}

In the 11-year periodstudied, eleven recurrent OKC cases and twelve recurrent ameloblastoma cases were operated. Patients' age, type of lesion, previous surgeries, and our treatment modality are shown in Table 1. Patient ages ranged from 29 to 72 years (mean $=44 \pm 11.91$ years). Most patients were referred to our department with complaints such as gradually growing mass, mandibular asymmetry, swelling, pain, trismus, or suppuration. Two patients had no complaint, but recurrences were diagnosed incidentally by routine radiography. The patients' prior treatments were marsupialization, enucleation, curettage or their combinations.

Recurrence occurred within 5 years after the first treatment in $69.5 \%(16 / 23)$ of patients. In seven cases (31.5\%), recurrence occurred between 6 and 11 years after the first treatment. The mean recurrence time was 4.2 years (range 3-11 years). There is a higher incidence of recurrence in the mandible (22/23) as compared to the maxilla (1/23), among which 9 were in the angle and ramus region, 6 were in corpus region, 5 were in angle region, 1 was in anterior region and 1 was in ramus region. There was statically significant relation between location and year of recurrence onset ( $p=0.004$; Table 2). One recurrence in 7 cases, two recurrence in 15 cases, and three recurrence in 1 case were recorded. The majority of lesions $(15 / 23,65 \%)$ were greater than $3.5 \mathrm{~cm}$ (mean, $4.3 \mathrm{~cm}$, range, $2.5-7 \mathrm{~cm}$ ). There was statically significant relation between diameter of lesion and year of recurrence onset $(p=0.026$; Table 3). Among the first treatments, enucleation exhibited most high recurrence rate (18/23; 78\%). Marsupialization with curettage, marsupialization with enucleation, and curettage had similar recurrence rates, with respective values of $0.9 \%$ (2/23), $0.4 \%(1 / 23)$, and $0.9 \%(2 / 23)$.

Of the 11 recurrent OKC patients, 6 were females and 5 were males with a male-to-female ratio of 1.2:1. The age of the recurrent OKC patients ranged from 31 to 57 years with a mean of 43.1 years. All recurrent OKCs were multilocular and parakeratotic. OKCs were located in the corpus region of the mandible in 3 cases (27\%), 1 case affected the posterior maxilla (10\%), 4 cases affected the angle area (36\%), and in 3 cases, the ramus and angle areas were involved (27\%). Impacted teeth were found to be related to $27 \%$ $(3 / 11)$ of total recurrent OKC cases when the initial OKC diagnosis was made.

Recurrent ameloblastoma were determined in 12 patients, of whom 6 were male and 5 were female. The age range was 29 to 72 years, with a mean age of 44.8 years. One tumor was identified in the anterior mandible (8\%), 1 in the angulus region, 1 in the ramus region, 3 in the corpus mandible region (25\%), and 6 in the angle and ramus region (67\%). All recurrent ameloblastomas were multicystic/solid type. Different histopathological subtypes of ameloblastomas were seen in our study (8 cases of follicular, 2 cases of plexiform, 
and 2 cases of granuler cell). When the initial diagnosis of ameloblastoma was made, four cases were associated with impacted teeth.

We performed marginal resection in ten patients, and segmental resection in thirteen patients. The reconstruction plate was used in three patients, TMJ prosthesis was used in one patient, reconstruction plate and total TMJ prosthesis were placed in five patients, nine patients underwent iliac bone grafting, and four patients underwent vascularized fibula grafting for reconstruction. Preoperative and postoperative representative images of two cases are shown in Figure 1 and 2. All patients healed with no serious complications. The follow-up period was ranging from 3 years to 11 (mean, $6.6 \pm 2.06$ years). No recurrence was observed during follow-up period.

Table 1. Clinical and histopathological appearance of the patients and treatment methods.

\begin{tabular}{|c|c|c|c|c|c|c|c|}
\hline $\begin{array}{l}\text { Case } \\
\text { No. }\end{array}$ & Age & Sex & Diagnosis & Complaints & Location & Previous surgical procedures & Our treatment approaches \\
\hline 1 & 32 & $\mathrm{~F}$ & $\begin{array}{l}\text { Follicular } \\
\text { Ameloblastoma }\end{array}$ & Swelling & $\begin{array}{l}\text { Right mandibular } \\
\text { angulus and } \\
\text { ramus }\end{array}$ & $\begin{array}{l}1 \text { marsupialisation and curettage } \\
\text { ( } 6 \text { years ago) } \\
1 \text { enucleation ( } 4 \text { years ago) }\end{array}$ & $\begin{array}{l}\text { Segmental resection, } \\
\text { reconstruction with free fibula } \\
\text { graft }\end{array}$ \\
\hline 2 & 34 & M & $\mathrm{OKC}$ & $\begin{array}{l}\text { Swelling, } \\
\text { pain }\end{array}$ & $\begin{array}{l}\text { Right mandibular } \\
\text { corpus }\end{array}$ & 1 enucleation (6 years ago) & $\begin{array}{l}\text { Marginal resection, reconstruction } \\
\text { with iliac graft }\end{array}$ \\
\hline 3 & 54 & M & $\mathrm{OKC}$ & $\begin{array}{l}\text { Trismus, } \\
\text { swelling }\end{array}$ & $\begin{array}{l}\text { Left mandibular } \\
\text { angulus and } \\
\text { ramus }\end{array}$ & $\begin{array}{l}1 \text { enucleation ( } 10 \text { years ago) } \\
1 \text { curettage ( } 8 \text { years ago) }\end{array}$ & $\begin{array}{l}\text { Segmental resection, } \\
\text { reconstruction plate and TMJ } \\
\text { prosthesis were placed }\end{array}$ \\
\hline 4 & 29 & $\mathrm{~F}$ & $\begin{array}{l}\text { Plexiform } \\
\text { Ameloblastoma }\end{array}$ & $\begin{array}{l}\text { Mandibular } \\
\text { asymmetry }\end{array}$ & $\begin{array}{l}\text { Left mandibular } \\
\text { corpus }\end{array}$ & 1 enucleation ( 3 years ago) & $\begin{array}{l}\text { Marginal resection, reconstruction } \\
\text { with iliac graft }\end{array}$ \\
\hline 5 & 35 & M & $\begin{array}{l}\text { Follicular } \\
\text { Ameloblastoma }\end{array}$ & - & $\begin{array}{l}\text { Right mandibular } \\
\text { corpus }\end{array}$ & $\begin{array}{l}1 \text { curettage (6 years ago) } \\
1 \text { enucleation ( } 2 \text { years ago) }\end{array}$ & $\begin{array}{l}\text { Marginal resection, reconstruction } \\
\text { with iliac graft }\end{array}$ \\
\hline 6 & 46 & $\mathrm{~F}$ & OKC & $\begin{array}{l}\text { Swelling, } \\
\text { pain, } \\
\text { suppuration }\end{array}$ & $\begin{array}{l}\text { Left mandibular } \\
\text { angulus }\end{array}$ & $\begin{array}{l}1 \text { marsupialisation and enucleation } \\
\text { (9 years ago) } \\
1 \text { curettage ( } 3 \text { years ago) }\end{array}$ & $\begin{array}{l}\text { Marginal resection, reconstruction } \\
\text { with iliac graft }\end{array}$ \\
\hline 7 & 55 & $\mathrm{~F}$ & $\begin{array}{l}\text { Follicular } \\
\text { Ameloblastoma }\end{array}$ & Swelling & $\begin{array}{l}\text { Right mandibular } \\
\text { angulus and } \\
\text { ramus }\end{array}$ & 2 enucleation ( 7 and 3 years ago) & $\begin{array}{l}\text { Segmental resection, } \\
\text { reconstruction plate and TMJ } \\
\text { prosthesis was placed }\end{array}$ \\
\hline 8 & 39 & $\mathrm{~F}$ & $\mathrm{OKC}$ & Pain & $\begin{array}{l}\text { Right mandibular } \\
\text { corpus }\end{array}$ & 2 enucleation ( 7 and 4 years ago) & $\begin{array}{l}\text { Marginal resection, reconstruction } \\
\text { with iliac graft }\end{array}$ \\
\hline 9 & 42 & $\mathrm{~F}$ & $\mathrm{OKC}$ & $\begin{array}{l}\text { Pain, } \\
\text { suppuration }\end{array}$ & $\begin{array}{l}\text { Left mandibular } \\
\text { angulus }\end{array}$ & $\begin{array}{l}2 \text { enucleation ( } 8 \text { and } 5 \text { years ago) } \\
1 \text { curettage ( } 2 \text { years ago) }\end{array}$ & $\begin{array}{l}\text { Marginal resection, reconstruction } \\
\text { with iliac graft }\end{array}$ \\
\hline 10 & 72 & M & $\begin{array}{l}\text { Follicular } \\
\text { Ameloblastoma }\end{array}$ & Swelling & $\begin{array}{l}\text { Left mandibular } \\
\text { angulus and } \\
\text { ramus }\end{array}$ & $\begin{array}{l}1 \text { enucleation ( } 15 \text { years ago) } \\
1 \text { enucleation ( } 4 \text { years ago) }\end{array}$ & $\begin{array}{l}\text { Segmental resection, } \\
\text { reconstruction plate is placed only }\end{array}$ \\
\hline 11 & 29 & M & $\begin{array}{l}\text { Granular cell } \\
\text { Ameloblastoma }\end{array}$ & Swelling & $\begin{array}{l}\text { Left mandibular } \\
\text { angulus and } \\
\text { ramus }\end{array}$ & 2 enucleation ( 8 and 6 years ago) & $\begin{array}{l}\text { Segmental resection, } \\
\text { reconstruction with free fibula } \\
\text { graft }\end{array}$ \\
\hline 12 & 46 & M & $\mathrm{OKC}$ & Pain, swelling & $\begin{array}{l}\text { Right mandibular } \\
\text { angulus }\end{array}$ & $\begin{array}{l}1 \text { marsupialisation and curettage } \\
\text { (6 years ago) }\end{array}$ & $\begin{array}{l}\text { Segmental resection, } \\
\text { reconstruction plate is placed only }\end{array}$ \\
\hline 13 & 58 & $\mathrm{~F}$ & $\begin{array}{l}\text { Follicular } \\
\text { Ameloblastoma }\end{array}$ & Swelling & $\begin{array}{l}\text { Right mandibular } \\
\text { angulus and } \\
\text { ramus }\end{array}$ & $\begin{array}{l}1 \text { enucleation ( } 7 \text { years ago) } \\
1 \text { curettage ( } 5 \text { years ago) }\end{array}$ & $\begin{array}{l}\text { Segmental resection, } \\
\text { reconstruction plate and TMJ } \\
\text { prosthesis was placed }\end{array}$ \\
\hline 14 & 38 & M & $\begin{array}{l}\text { Follicular } \\
\text { Ameloblastoma }\end{array}$ & $\begin{array}{l}\text { Mandibular } \\
\text { asymmetry }\end{array}$ & $\begin{array}{l}\text { Right mandibular } \\
\text { corpus }\end{array}$ & 1 enucleation (6 years ago) & $\begin{array}{l}\text { Marginal resection, reconstruction } \\
\text { with iliac graft }\end{array}$ \\
\hline
\end{tabular}




\begin{tabular}{|c|c|c|c|c|c|c|c|}
\hline $\begin{array}{l}\text { Case } \\
\text { No. }\end{array}$ & Age & Sex & Diagnosis & Complaints & Location & Previous surgical procedures & Our treatment approaches \\
\hline 15 & 46 & M & $\begin{array}{l}\text { Follicular } \\
\text { Ameloblastoma }\end{array}$ & Swelling & $\begin{array}{l}\text { Right mandibular } \\
\text { angulus }\end{array}$ & 2 enucleation (7 and 2 years ago) & $\begin{array}{l}\text { Segmental resection, } \\
\text { reconstruction with free fibula } \\
\text { graft }\end{array}$ \\
\hline 16 & 31 & M & $\mathrm{OKC}$ & Trismus, Pain & $\begin{array}{l}\text { Left mandibular } \\
\text { corpus }\end{array}$ & 1 enucleation (2 years ago) & $\begin{array}{l}\text { Marginal resection, reconstruction } \\
\text { with iliac graft }\end{array}$ \\
\hline 17 & 44 & M & $\mathrm{OKC}$ & $\begin{array}{l}\text { Swelling, } \\
\text { Pain }\end{array}$ & $\begin{array}{l}\text { Right mandibular } \\
\text { angulus and } \\
\text { ramus }\end{array}$ & $\begin{array}{l}1 \text { enucleation ( } 8 \text { years ago) } \\
1 \text { curettage ( } 3 \text { years ago) }\end{array}$ & $\begin{array}{l}\text { Segmental resection, } \\
\text { reconstruction plate and TMJ } \\
\text { prosthesis was placed }\end{array}$ \\
\hline 18 & 57 & $\mathrm{~F}$ & $\mathrm{OKC}$ & Swelling & $\begin{array}{l}\text { Right mandibular } \\
\text { angulus and } \\
\text { ramus }\end{array}$ & $\begin{array}{l}1 \text { enucleation ( } 10 \text { years ago) } \\
1 \text { curettage ( } 5 \text { years ago) }\end{array}$ & $\begin{array}{l}\text { Segmental resection, } \\
\text { reconstruction plate and TMJ } \\
\text { prosthesis was placed }\end{array}$ \\
\hline 19 & 35 & $\mathrm{~F}$ & $\begin{array}{l}\text { Plexiform } \\
\text { Ameloblastoma }\end{array}$ & - & Anterior mandible & 1 enucleation (4 years ago) & $\begin{array}{l}\text { Marginal resection, reconstruction } \\
\text { with iliac graft }\end{array}$ \\
\hline 20 & 45 & $\mathrm{~F}$ & $\mathrm{OKC}$ & $\begin{array}{l}\text { Pain, } \\
\text { Suppuration }\end{array}$ & $\begin{array}{l}\text { Left mandibular } \\
\text { angulus }\end{array}$ & $\begin{array}{l}1 \text { enucleation ( } 8 \text { years ago) } \\
1 \text { curettage ( } 3 \text { years ago) }\end{array}$ & $\begin{array}{l}\text { Segmental resection, } \\
\text { reconstruction with free fibula } \\
\text { graft }\end{array}$ \\
\hline 21 & 68 & $\mathrm{~F}$ & $\begin{array}{l}\text { Follicular } \\
\text { Ameloblastoma }\end{array}$ & Swelling & $\begin{array}{l}\text { Left mandibular } \\
\text { angulus and } \\
\text { ramus }\end{array}$ & $\begin{array}{l}1 \text { enucleation ( } 12 \text { years ago) } \\
1 \text { curettage ( } 6 \text { years ago) }\end{array}$ & $\begin{array}{l}\text { Segmental resection, } \\
\text { reconstruction plate is only placed }\end{array}$ \\
\hline 22 & 41 & M & $\begin{array}{l}\text { Granuler cell } \\
\text { Ameloblastoma }\end{array}$ & Pain, swelling & $\begin{array}{l}\text { Right mandibular } \\
\text { ramus }\end{array}$ & 1 enucleation (6 years ago) & $\begin{array}{l}\text { Segmental resection, } \\
\text { reconstruction with TMJ prosthesis }\end{array}$ \\
\hline 23 & 36 & $\mathrm{~F}$ & OKC & Swelling & Maxilla posterior & $\begin{array}{l}1 \text { curettage ( } 7 \text { years ago) } \\
1 \text { enucleation ( } 4 \text { years ago) }\end{array}$ & Marginal resection \\
\hline
\end{tabular}

OKC; odontogenic keratocyst.

Table 2. Comparison between location and year of recurrence onset.

\begin{tabular}{|c|c|c|c|}
\hline \multirow[b]{2}{*}{ Location, n (\%) } & \multicolumn{2}{|c|}{ Year of recurrence onset } & \multirow[b]{2}{*}{$P$} \\
\hline & $0-5$ years & $6-11$ years & \\
\hline Angulus\&ramus & 7 (43.75) & $2(28.6)$ & \\
\hline Corpus & $4(25)$ & $2(28.6)$ & \\
\hline Angulus & $3(18.75)$ & $2(28.6)$ & \\
\hline Ramus & $0(0)$ & $1(14.2)$ & $0.004^{*}$ \\
\hline Mand. anterior & $1(6.25)$ & $0(0)$ & \\
\hline Max. posterior & $1(6.25)$ & $0(0)$ & \\
\hline Total (n) & 16 & 7 & \\
\hline
\end{tabular}

n, number.

* Statically significant as indicated in P values.

Table 3. Comparison between lesion diameter and year of recurrence onset.

\begin{tabular}{|c|c|c|c|}
\hline \multirow[b]{2}{*}{ Lesion diameter, n (\%) } & \multicolumn{2}{|c|}{ Year of recurrence onset } & \multirow[b]{2}{*}{$P$} \\
\hline & $0-5$ years & $6-10$ years & \\
\hline$<3.5 \mathrm{~cm}$ & $4(25)$ & $4(57)$ & \\
\hline$>3.5 \mathrm{~cm}$ & $12(75)$ & $3(43)$ & $0.026^{\star}$ \\
\hline Total (n) & 16 & 7 & \\
\hline
\end{tabular}




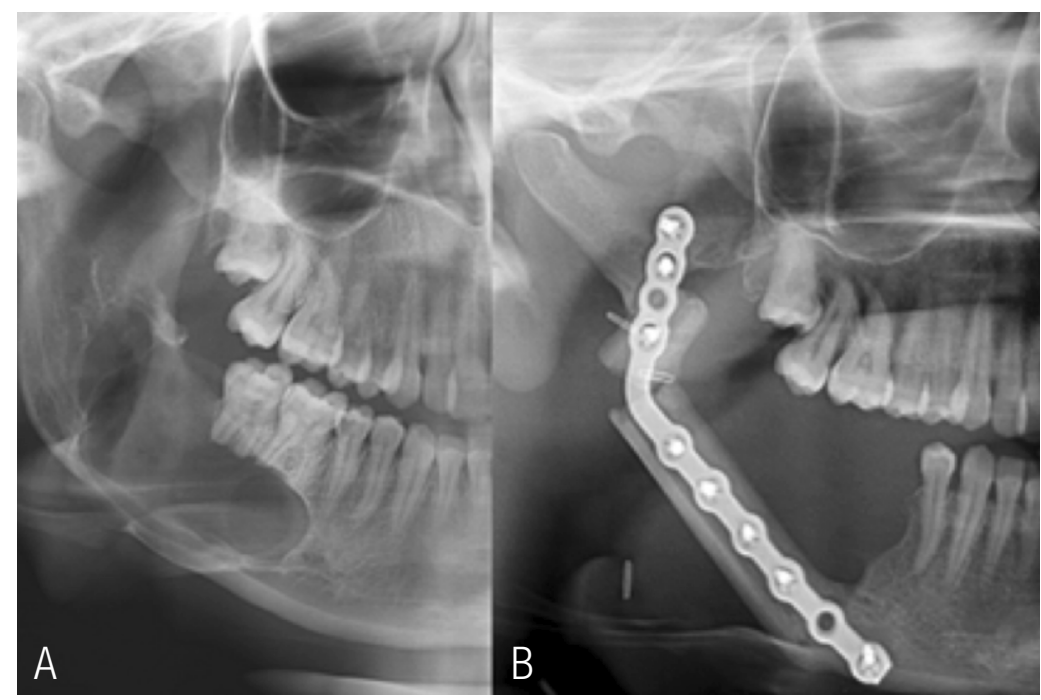

Figure 1. Representative radiological examination of one case of ameloblastoma. A) Ameloblastoma in right mandible. B) Reconstruction with free vascularized fibula graft after resection.

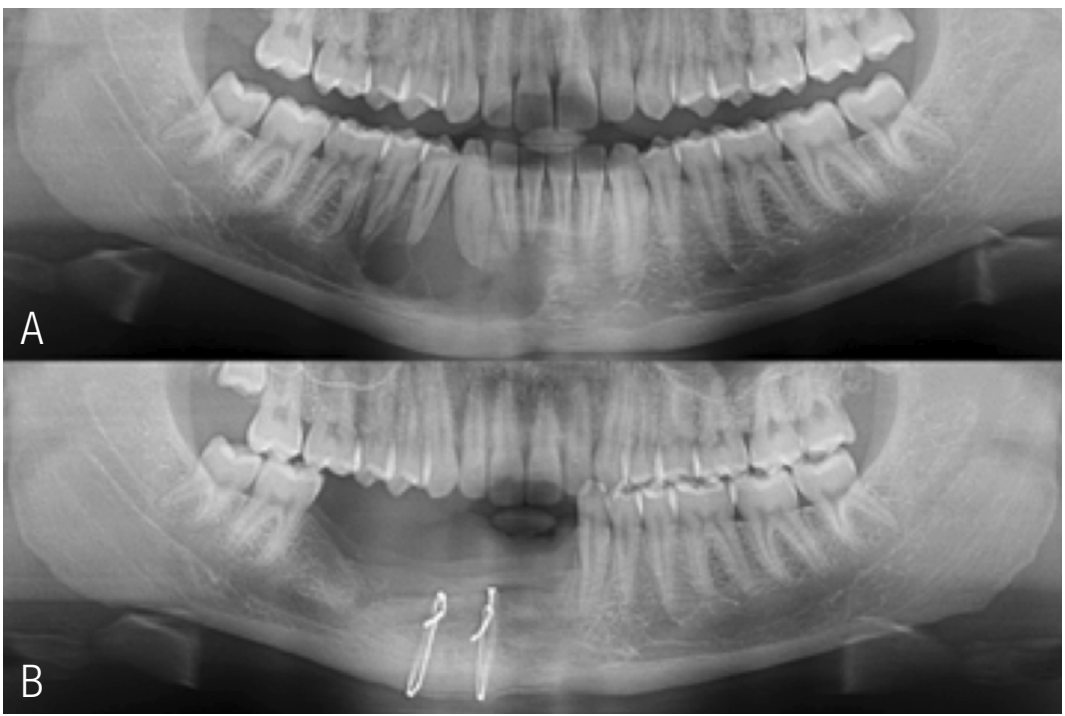

Figure 2. Representative radiological examination of one case of OKC. A) Odontogenic keratocyst in right mandible. B) Reconstruction with iliac graft. 
DISCUSSION

Odontogenic keratocyst is a benign neoplasm of odontogenic origin and comprises $4-12 \%$ of all odontogenic cysts (12). The main symptoms are swelling, pain, pus discharge or trismus (13). Because of its aggressive clinical behavior, high recurrence rate, association with nevoid basal cell carcinoma syndrome, and presence of the PTCH tumor suppressor gene mutation, the WHO classified this lesion as a neoplasia in 2005 and named it 'keratocystic odontogenic tumor' (14). In 2017, the odontogenic keratocyst returned to its original and currently accepted terminology 'odontogenic keratocyst (OKC)' because PTCH gene mutations are also found in non-neoplastic lesions, and resolution of the cyst after marsupialization is incompatible with a neoplastic process $(4,14)$. Orthokeratinized odontogenic cyst (OOC) was formerly accepted as a type of OKC, but this cyst is included in the 2017 classification as a separate entity. The OOC cavity is entirely or predominantly lined by orthokeratinized stratified squamous epithelium $(6,14)$. The presence of parakeratinized epithelium on the lesion wall is the key microscopic feature for a diagnosis of OKC rather than OOC $(6,15)$.

Odontogenic keratocyst has the potential for recurrence, similar to ameloblastoma. The recurrence rate of $\mathrm{OKC}$ is $0-62.5 \%$ (16). Recurrence rates may be affected by the treatment modality, lesion size, follow-up duration, and histopathological presence of daughter cysts $(4,7,16)$. Most studies focus on surgical treatment in relation to the recurrence of the lesion (2). Reports in the literature consider treatment methods of OKC varying from marsupialization to resection $(7,16)$. Simple enucleation is not recommended due to the high recurrence rate. Enucleation with application of Carnoy's solution or peripheral osteotomy is recommended in small OKC cases whose margins can be evaluated (7). Meara et al. (17) treated 49 OKC cases with enucleation, with a followup period of 1-15 years; the recurrence rate was
$35 \%$. Similarly, in our study, the highest recurrence rate was seen in cases treated with enucleation. Two-stage treatment or resection is recommended for large and expanding OKCs. Marsupialization followed by enucleation or adjunctive measures can be performed to decrease the surgical injury to the patient. If patient compliance with irrigating the cyst orifice is doubtful, enucleation with adjunctive measures or resection is recommended $(1,2,7)$. Additionally, conservative treatments such as marsupialization and decompression may leave behind cystic tissue. Most surgeons advocate complete removal of the lesion, and marsupialization should not be the treatment of choice (16). Zecha et al. (1) found a recurrence rate of $40 \%$ in 10 OKC cases treated by marsupialization. In our study, marsupialization was recorded among the previous treatments of some cases.

Care should be taken to completely remove the cyst epithelium without leaving remnant adjacent bone or soft tissue because the cyst epithelium is thin and friable. The remaining satellite cysts serve as nidus for recurrence. Multilocular cysts are more problematic and removing them in one piece is difficult $(2,4,16)$. Smaller lesions tend to be unilocular, whereas larger lesions tend to be multilocular (5). In our study, all of OKC cases were multilocular. Multilocular OKCs of $>3.5 \mathrm{~cm}$ in diameter have a high recurrence rate (18). In consistent with the literature, $65 \%$ of cases were larger than $3.5 \mathrm{~cm}$ in diameter in our study. However, no significant relation was found between the number of recurrences and lesion diameter. This may be due to low number of cases. For these reasons, large or recurrent OKC lesions require aggressive treatment $(5,16)$. Radical resection with or without continuity defects should be applied for recurrent lesions (7). Marginal or segmental resection has the lowest recurrence rate among all treatments. Although this is not the first treatment option for many tumors, it is recommended in cases of multiple recurrences (7). Bataineh et al. (16) reported no recurrence 
in 31 OKC cases treated with marginal resection during a 2-8-year follow up. We performed radical approaches because at least one recurrence had occurred in our cases; therefore, no recurrence developed during the follow up period.

Some authors have suggested excision in the soft tissue covering the cyst, and reported that new OKCs can develop from the basal layer of the oral epithelium $(7,16)$. Odontogenic keratocysts may develop from the overlying mucosa and penetrate to the graft, leading to recurrence (7). For this reason, we excised the mucosa overlying the lesion in all cases.

Odontogenic keratocysts are mostly located in the mandible, especially in the posterior portion of the mandible $(2,16)$. In our study, there were seven cases in posterior mandible and one case in the posterior maxilla. The relationship of tumor location with recurrence has also been controversial. Some authors have argued that there is no significant relation between recurrence and the tumor location, while others have reported a significant relationship between recurrence and lesions in the posterior mandible $(13,19)$. It has been reported that reaching the depths of the mandible can be difficult, especially in large cases (16). This may be the reason for more recurrence in the posterior mandible in this study.

Association of OKCs with impacted teeth is said to be in the range of $25-40 \%$. Unlike dentigerous cysts where its development actively causes impaction by pressure of the cystic fluid on the tooth, impaction in OKC is presumably a passive collateral event secondary to its growth (2). In this study, $27 \%$ of OKC cases are related to the impacted teeth.

Ameloblastoma is a rare, slowly growing, usually painless, invasive, benign odontogenic neoplasm. Patients most commonly complain a painless swelling or expansion of the jaw causing facial asymmetry
$(20,21)$. Ameloblastomas were categorized as unicystic, desmoplastic, extraosseous/peripheral, and solid/multicystic types in the 2005 classification (22). In the 2017 classification, the term solid/ multicystic was dropped because most conventional ameloblastomas show cystic degeneration without biological differences; ameloblastomas are now classified as ameloblastoma, unicystic ameloblastoma, and extraosseous/peripheral types (14). The desmoplastic type remains a histopathologic subtype instead of becoming a separate entity; the histological subtypes of ameloblastoma are follicular, plexiform, acanthomatous, granular cell, basaloid, and desmoplastic (14). The major histopathologic variants of ameloblastoma are follicular and plexiform types followed by acanthomatous and granular cell types (11). In this study, eight cases were follicular, two were plexiform, and two were granuler cell type.

Recurrence may be influenced by the histological type, treatment modality, and tumor location $(22,23)$. Ameloblastomas can be treated by conservative and radical approaches (22). Conservative treatments involve enucleation with adjunctive procedures such as chemical cauterization or peripheral ostectomy with a 1-1.5-cm margin. This can be applied for unicysttype but is not suitable for multicystic/solid type ameloblastomas $(9,22)$. However, according to Ackermann et al. (24), aggressive surgery should also be performed in some unicystic ameloblastoma cases if the tumor is present in the connective tissue wall rather than the epithelium of the lesion, as this indicates infiltration. Radical approaches is indicated for recurrent cases and larger ameloblastomas involving the inferior alveolar canal or lower. The radical approach comprises segmental or marginal resection involving healthy bone 1.5-2 $\mathrm{cm}$ beyond the radiological margin $(22,23)$. The recurrence rate after conservative treatment is higher than that following aggressive treatment $(9,10,20)$. Nakamura et al. (25) reported a $7.1 \%$ recurrence rate after radical 
surgery and $33.3 \%$ after conservative treatment in 78 ameloblastoma cases. Despite the relatively high recurrence rate associated with conservative methods, the need for radical surgery for cystic tumors can be eliminated using a conservative approach (25). Sampson and Pogrel (26) reported that curettage of ameloblastomas resulted in high recurrence rates and indicated that during the first operation, soft-tissue spread should be prevented to reduce or eliminate the need for further extensive surgery in the event of recurrence. The solid/multicystic subtype, representing more than $80 \%$ of all cases, is more aggressive and more commonly recurrent than the unicystic subtype (20). Our study included twelve cases of recurrent ameloblastoma, all of which were of the solid/ multicystic type. All of the cases had previously been treated with conservative methods, but recurrence necessitated aggressive treatment approaches. For this reason, we performed marginal or segmental resection with healthy margins in these cases and no evidence of recurrence was found during the follow-up period after our treatments.

Inadequate resection of hard and soft tissues beyond an ameloblastoma causes recurrence $(10,22)$. Tumor cells remaining in areas of osteotomy after inadequate resection can lead to tumorigenesis in the graft. Periosteum invasion may cause tumor cells to spread to soft tissue. For this reason, the free margins should be determined histologically before reconstruction $(9,10,22)$. We performed soft-tissue resection and conducted histopathological evaluation before reconstruction in all cases.

The follicular, granular cell, and acanthomatous types are associated with recurrence (27). Follicular ameloblastoma is characterized by highest recurrent rate as compared to other variants of ameloblastoma (22). In our study, the most common histopathological subtype was follicular ameloblastoma. Ameloblastomas are most commonly found in the mandible (85\%, usually in the molar-elevated ramus region), maxilla (15\%, usually in the third molar area) and rarely other sites $(8,21)$. All ameloblastomas occurred in mandible in this study. The mandibular posterior region is the most common site of recurrence, and a cancellous portion of the lesion may project beyond the radiologic margin. Approximately $80 \%$ of ameloblastomas develop in the posterior mandible (8). Eight (67\%) of the twelve ameloblastomas were located in posterior mandible in our study. These findings are in accordance with previous studies.

It has been reported in the literature that ameloblastomas occur in association with an impacted or unerupted tooth (mostly the mandibular third molar) in $15 \%$ to $40 \%$ of cases (28). In consistent with the published data, $33.3 \%$ of cases are related to the impacted teeth in our study.

Malign transformation is extremely rare but can be caused by repeated postsurgical recurrence $(8,9)$. When ameloblastoma is diagnosed, the possibility of malignant transformation should be considered. Immediate effective treatment of an ameloblastoma is important to eliminate the risk of malignant transformation (9).

In the present study, the follow-up interval was 3-11 years. In addition, follow-up for 5 to 10 years is indicated, and we report here cases of recurrence after 10 years. One study reported a recurrence of OKC 41 years after the first surgery (29). Because most recurrences of ameloblastomas and OKCs occur within the first 5 years after surgery, annual clinical and radiological followup is recommended $(5,9,16,23)$. In our study, recurrence mostly occurred within 5 years after the first treatment.

Management of ameloblastomas and OKCs remains a subject of some debate. The aggressive characteristics of both lesions can cause recurrence, especially after conservative treatments. Although 
radical surgery, including segmental or marginal resection of the jaw, is generally recommended, some authors have advocated more conservative methods as the first line treatment modality in some cases $(3,12,23)$. Initial surgical approach correlated with risk of recurrence, local disease aggressiveness, and mortality (30), and enucleation exhibited most high recurrence rate in our study. Any recurrence will increase the degree of tissue damage and the need for further surgery. This can be avoided by applying appropriate treatments, including bone and soft tissue resection. For recurrent OKCs or ameloblastomas, marginal or segmental resection with safety margins is the most suitable method for maintaining disease-free survival. Diameter and location of lesion should be taken into consideration in treatment planning. Because these factors were associated with the time of recurrence according to our study results.

The present study also had some limitations. First, the number of patients was low. Clinical, radiological, and histological study in larger groups will provide added information in the management. Second, no control group such as patients without recurrence were used.

\section{CONCLUSION}

According to our findings, a resection with some safety margin is the best method for treating recurrent OKC and ameloblastoma cases. In addition, radical treatments should be considered for the treatment of lesions that are difficult to reach for anatomical reasons and larger than $3.5 \mathrm{~cm}$. These findings need to be confirmed by future researches with an appropriate design to overcome the present study's limitations.

\section{REFERENCES}

1. Zecha J. A., Mendes R. A., Lindeboom V. B., van der Waal I. Recurrence rate of keratocystic odontogenic tumor after conservative surgical treatment without adjunctive therapies - A 35-year single institution experience. Oral Oncol. 2010; 46 (10): 740-2.

2. Bello I. O. Keratocystic odontogenic tumor: A biopsy service's experience with 104 solitary, multiple and recurrent lesions. Med Oral Patol Oral Cir Bucal. 2016; 21 (5): e538-46.

3. Zhao Y. F., Wei J. X., Wang S. P. Treatment of odontogenic keratocysts: a follow-up of 255 Chinese patients. Oral Surg Oral Med Oral Pathol Oral Radiol Endod. 2002; 94 (2): 151-6.

4. Ribeiro-Junior O., Borba A. M., Alves C. A. F., Gouveia M. M., Deboni M. C. Z., Naclerio-Homem MDG. Reclassification and treatment of odontogenic keratocysts: A cohort study. Braz Oral Res. 2017; 31: e98.

5. Chrcanovic B. R., Gomez R. S. Recurrence probability for keratocystic odontogenic tumors: An analysis of 6427 cases. J Craniomaxillofac Surg. 2017; 45 (2): 244-51.

6. Gonzalez Galvan $\mathrm{M}$ del C., GarciaGarcia A., Anitua-Aldecoa E., MartinezConde Llamosas R., Aguirre-Urizar J. M. Orthokeratinized odontogenic cyst: a report of three clinical cases. Case Rep Dent. 2013; 2013: 672383.

7. Johnson N. R., Batstone M. D., Savage N. W. Management and recurrence of keratocystic odontogenic tumor: a systematic review. Oral Surg Oral Med Oral Pathol Oral Radiol. 2013; 116 (4): e271-6. 
8. Parmar S., Al-Qamachi L., Aga H. Ameloblastomas of the mandible and maxilla. Curr Opin Otolaryngol Head Neck Surg. 2016; 24 (2): 148-54.

9. Faras F., Abo-Alhassan F., Israel Y., Hersant B., Meningaud J. P. Multi-recurrent invasive ameloblastoma: A surgical challenge. Int $\mathrm{J}$ Surg Case Rep. 2017; 30: 43-5.

10. Mendenhall W. M., Werning J. W., Fernandes R., Malyapa R. S., Mendenhall N. P. Ameloblastoma. Am J Clin Oncol. 2007; 30 (6): 645-8.

11. Nakamura N., Mitsuyasu T., Higuchi Y., Sandra F, Ohishi M. Growth characteristics of ameloblastoma involving the inferior alveolar nerve: a clinical and histopathologic study. Oral Surg Oral Med Oral Pathol Oral Radiol Endod. 2001; 91 (5): 557-62.

12. Grasmuck E. A., Nelson B. L. Keratocystic odontogenic tumor. Head Neck Pathol. 2010; 4 (1): 94-6.

13. Habibi A., Saghravanian N., Habibi M., Mellati E., Habibi M. Keratocystic odontogenic tumor: a 10-year retrospective study of 83 cases in an Iranian population. J Oral Sci. 2007; 49 (3): 229-35.

14. Soluk-Tekkesin M., Wright J. M. The World Health Organization Classification of Odontogenic Lesions: A Summary of the Changes of the 2017 (4th) Edition. Turk Patoloji Derg. 2018; 34 (1).

15. Wright J. M., Vered M. Update from the 4th Edition of the World Health Organization Classification of Head and Neck Tumours: Odontogenic and Maxillofacial Bone Tumors. Head Neck Pathol. 2017; 11 (1): 68-77.

16. Bataineh A. B., al Qudah M. Treatment of mandibular odontogenic keratocysts. Oral Surg Oral Med Oral Pathol Oral Radiol Endod. 1998; 86 (1): $42-7$.

17. Meara J. G., Shah S., Li K. K., Cunningham M. J. The odontogenic keratocyst: a 20 -year clinicopathologic review. Laryngoscope. 1998; 108 (2): 280-3.
18. Ianculovici C., Blinder D., O Peleg. Trends in recurrence of keratocystic odontogenic tumor. Int J Oral Dent Health. 2016; 2 (3): 1-4.

19. Myoung H., Hong S. P., Hong S. D., Lee J. I., Lim C. Y., Choung P. H., et al. Odontogenic keratocyst: Review of 256 cases for recurrence and clinicopathologic parameters. Oral Surg Oral Med Oral Pathol Oral Radiol Endod. 2001; 91 (3): 328-33.

20. Infante-Cossio P., Prats-Golczer V., GonzalezPerez L. M., Belmonte-Caro R., Martinez DEFR, Torres-Carranza E., et al. Treatment of recurrent mandibular ameloblastoma. Exp Ther Med. 2013; 6 (2): 579-83.

21. Figueiredo N. R., Dinkar A. D., Meena M., Satoskar S., Khorate M. Ameloblastoma: A clinicoradiographic and histopathologic correlation of 11 cases seen in Goa during 20082012. Contemp Clin Dent. 2014; 5 (2): 160-5.

22. Aramanadka C., Kamath A. T., Kudva A. Recurrent Ameloblastoma: A Surgical Challenge. Case Rep Dent. 2018; 2018: 8271205.

23. Carlson E. R., Marx R. E. The ameloblastoma: primary, curative surgical management. J Oral Maxillofac Surg. 2006; 64 (3): 484-94.

24. Ackermann G. L., Altini M., Shear M. The unicystic ameloblastoma: a clinicopathological study of 57 cases. J Oral Pathol. 1988; 17 (910): 541-6.

25. Nakamura N., Higuchi Y., Mitsuyasu T., Sandra F., Ohishi M. Comparison of long-term results between different approaches to ameloblastoma. Oral Surg Oral Med Oral Pathol Oral Radiol Endod. 2002; 93 (1): 13-20.

26. Sampson D. E., Pogrel M. A. Management of mandibular ameloblastoma: the clinical basis for a treatment algorithm. J Oral Maxillofac Surg. 1999; 57 (9): 1074-7; discussion 8-9.

27. Hong J., Yun P. Y., Chung I. H., Myoung H., Suh J. D., Seo B. M., et al. Long-term follow up on recurrence of 305 ameloblastoma cases. Int J Oral Maxillofac Surg. 2007; 36 (4): 283-8. 
28. Mortazavi H., Baharvand M. Jaw lesions associated with impacted tooth: A radiographic diagnostic guide. Imaging Sci Dent. 2016; 46 (3): 147-57.

29. Crowley T. E., Kaugars G. E., Gunsolley J. C. Odontogenic keratocysts: a clinical and histologic comparison of the parakeratin and orthokeratin variants. J Oral Maxillofac Surg. 1992; 50 (1): 22-6.

30. Milman T., Lee V., LiVolsi V. Maxillary Ameloblastoma with Orbital Involvement: An Institutional Experience and Literature Review. Ophthalmic Plast Reconstr Surg. 2016;32(6):441-6. 